\title{
Kilka uwag na temat polemiki Plutarcha ze stoikami
}

\author{
Michat DAMSKI*
}

\begin{abstract}
Some comments on the polemics of Plutarch with Stoics: The purpose of this article is to briefly discuss several key anti-stoic arguments presented in Plutarch's polemical texts De stoicorum repugnantiis and De communibus notitiis adversus stoicos. The paper argues that the polemic against Stoicism is rather ill-disposed and that the presented arguments, despite their rhetorical power and elegancy in language, show an insufficient understanding of the criticised doctrine.
\end{abstract}

\section{SEOWA KLUCZOWE}

Stoic philosophy; ethics; stoic sage; moral progress; Chrysippus; Plutarch of Chaeronea

* Mgr, doktorant w Instytucie Filozofii Uniwersytetu Warszawskiego. E-mail: m.damski @gmail.com. 
Nie ulega wątpliwości, że stoicyzm zalicza się do raczej kontrowersyjnych propozycji filozoficznych, przede wszystkim ze względu na właściwe tej szkole kontrintuicyjne i sprzeczne z codziennym doświadczeniem tezy z dziedziny etyki. Istotnie trudno bez zastrzeżeń zaakceptować słynne stoickie twierdzenia, że sprawy takie jak zdrowie, bogactwo, liczba przyjaciół czy pozycja społeczna nie mają żadnego wpływu na szczęśliwe życie lub że tylko mędrzec jest człowiekiem wolnym, a wszyscy inni ludzie to niewolnicy. Jednocześnie jest to filozofia, która od czasów starożytnych aż po współczesność wzbudza niesłabnące zainteresowanie i to zarówno ze strony jej zdecydowanych krytyków, jak i komentatorów nastawionych niezwykle entuzjastycznie, niestety nazbyt często niepotrafiących dostrzec istotnych kwestii dyskusyjnych i problematycznych (Irvine, 2009). Zarzuty, jakie formułowane są przeciw filozofii Portyku, dotyczą zarówno jej sfery teoretycznej, w której zawierają się twierdzenia z dziedziny metafizyki, jak i sfery czysto praktycznej, mającej wprawdzie silne zakorzenienie w teorii, jednak odnoszącej się przede wszystkim do wysiłków skierowanych na realizowanie określonego sposobu życia.

W trzech tekstach polemicznych Plutarcha ${ }^{1}$ znaleźć można zarzuty odnoszące się do obydwu wspomnianych sfer filozofii stoickiej, celem niniejszego artykułu zaś będzie przeprowadzenie ich analizy. W rezultacie możliwa będzie próba udzielenia odpowiedzi na pytanie o trafność owych zarzutów, jak również stwierdzenie, czy krytyka Plutarcha uwzględnia i w przekonujący sposób odpiera argumenty samych stoików. Pod uwagę brane będą oczywiście jedynie argumenty występujące $\mathrm{w}$ tych tekstach źródłowych, które z dużym prawdopodobieństwem były znane platońskiemu filozofowi. Należy przy tym podkreślić, że przyjęta metodologia jest jak najdalsza od przeprowadzania krytyki stanowiska Plutarcha z poziomu współczesnego badacza filozofii stoickiej, a więc osoby posiadającej stosunkowo łatwy dostęp do ogromnej liczby opracowań naukowych oraz takich tekstów źródłowych, których sam Plutarch najprawdopodobniej nie znał lub też znać nie mógł.

Poniżej omówione zostaną trzy argumenty, które można uznać zarazem za najcięższe, jak i za najbardziej interesujące z punktu widzenia filozoficznego.

\section{ZARZUT DO ŻYCIA ZGODNEGO Z NATURA}

Pierwszy z omawianych zarzutów odnosi się do teoretycznych aspektów filozofii stoickiej i związany jest z używanym w tej szkole pojęciem natury ( z propagowanym ideałem życia $\mathrm{z}$ nią zgodnego. Trudności w tym wypadku pojawiają się przede wszystkim na poziomie definicyjnym, przy czym szczególnie problematyczne jest ustalenie czy na gruncie filozofii Portyku można

${ }^{1}$ De Stoicorum repugnantiis (dalej: Stoic. Rep.), De communibus notitiis adversus Stoicos (dalej: Comm. Not.) oraz Compendium Argumenti Stoicos absurdiora poetis dicere. 
w sensowny sposób stwierdzić, że natura jest dobra. Jeśli nie jest to możliwe, również życie zgodne z naturą nie będzie niczym dobrym. Argumentacja Plutarcha opiera się na dwóch przesłankach: (1) jeśli argument w dyskusji lub prawo nie są dobre, nic nie zobowiązuje do poddawania się im, oraz (2) sama natura nie jest dobra, a zalicza się do kategorii rzeczy obojętnych. Nie można więc stwierdzić, że życie zgodne z naturą jest czymś dobrym czy pożądanym, i nie należy również nakładać na człowieka takiego obowiązku. Stanowisko to najtrafniej i najkrócej zostało wyrażone w poniższym fragmencie:

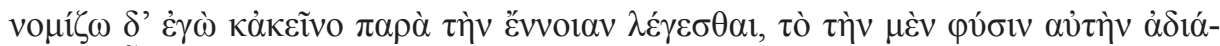

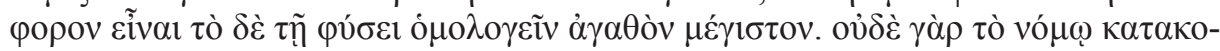

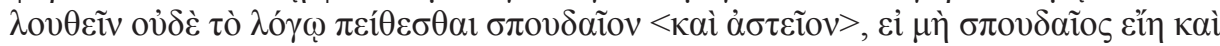

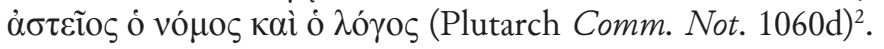

Sądzę ponadto, że i to mówią wbrew powszechnemu rozumieniu, iż sama natura jest czymś obojętnym, życie zaś podług tejże - najwyższym dobrem. Nie jest bowiem rzeczą właściwą czy zacną iść za prawem czy argumentem, o ile to prawo czy argument same nie będą zacne i właściwe.

Tymczasem bardzo istotny, choć nie od razu dostrzegalny błąd w tej argumentacji znajduje się już na poziomie drugiej przesłanki. Plutarchowi znane było oczywiście stanowisko stoików, wedle którego wszelkie dobra (w rozumieniu potocznym), takie jak bogactwo czy zdrowie, są w istocie czymś obojętnym, podobnie zresztą jak wszelkie rzeczy powszechnie uznawane za nieszczęścia. Jednocześnie jasne jest, że wiele z tych rzeczy, a w szczególności zdrowie, pochodzi pośrednio lub bezpośrednio z natury. Często przecież ludzie rodzą się szczególnie podatni na choroby lub z wadami wrodzonymi; do rzadkości nie należą również sytuacje takie, jak utrata majątku z przyczyn naturalnych, czego najprostszy przykład stanowić może zatonięcie okrętu podczas burzy. $\mathrm{Na}$ tej podstawie łatwo sformułować wniosek, że skoro za sprawą natury dzieją się rzeczy zaliczane do obojętnych, sama natura również jest czymś, co nie jest ani dobre, ani złe.

Wniosek taki stoi w całkowitej sprzeczności ze stoickim rozumieniem tego pojęcia. Filozofia Portyku widziała w świecie przede wszystkim ład i porządek, który powstaje za sprawą doskonałej i rozumnej istoty boskiej zarządzającej wszystkim w sposób opatrznościowy (Diogenes Laertios VII 147). Nie może być tu również mowy o oddzieleniu Boga od natury - te dwa kluczowe dla filozofii stoickiej pojęcia były ze sobą utożsamiane w sposób jednoznaczny i niebudzący wątpliwości:

${ }^{2}$ Greckie cytaty z Moraliów wg TLG Online (Thesaurus Linguae Graecae® Digital Library. (Ed. M. C. Pantelia). Irvine: University of California. Dostęp: http://www.tlg.uci.edu). Cytaty z Comm. Not. przełożyła na użytek artykułu Joanna Komorowska. 


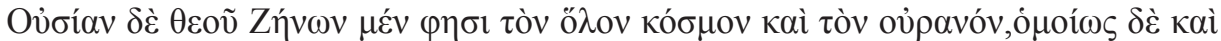
X Laertios VII 148 = Stoicorum Veterum Fragmenta, I, fr. 163).

Substancją boga jest - według Zenona - cały świat i niebo; to samo mówi Chryzyp w pierwszej księdze traktatu $O$ bogach i Posejdonios również w pierwszej księdze traktatu pod tym samym tytułem (przeł. K. Leśniak).

Można zatem stwierdzić, że dla stoików, czego nie zauważa Plutarch, sama natura dobra jest w tym sensie, że w swojej istocie nie jest ona niczym innym jak boskim logosem, a zatem życie zgodne z naturą oznacza właśnie życie zgodne z logosem, za sprawą którego na świecie panuje ład i porządek ${ }^{3}$. Podobna myśl, w sposób jednoznaczny wyrażająca stoickie przekonanie o istniejącym za sprawą opatrzności porządku we wszechświecie, wyrażona została w jeszcze innym miejscu:

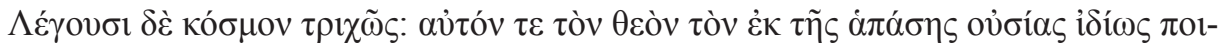

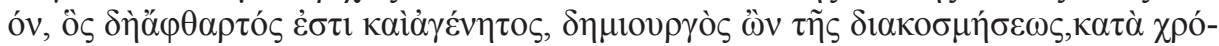
v

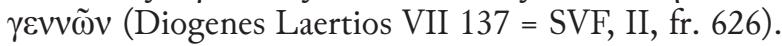

Świat stoicy rozumieją trojako: najpierw nazywają go samym Bogiem, nosicielem jednorodnej jakości wszelkiej substancji; jest on niezniszczalny i niestworzony, i jest twórcą ładu we wszechświecie; to on po upływie czasów wchłonie w siebie całą substancję i znowu ją z siebie zrodzi (przeł. K. Leśniak).

Stwierdzając, że natura zdaniem stoików nie jest czymś dobrym i że z tego powodu życie z nią zgodne jest z propozycją sprzeciwiającą się zdrowemu rozsądkowi. Plutarch zdaje się zwyczajnie nie rozumieć stanowiska krytykowanej przez siebie szkoły, a jego argumentacja w tym wypadku, mimo wysokiego poziomu retorycznego i językowego, ostatecznie trafia w próżnię.

\section{ARGUMENT DOTYCZĄCY KATEGORII RZECZY OBOJĘTNYCH}

Zarzut drugi, choć ściśle powiązany z pierwszym, zachowuje jednak nieco inny charakter, odchodzi bowiem od zagadnień związanych z metafizyką czy z teorią etyki, ograniczając się wyłącznie do praktycznej strony filozofii stoickiej. Po-

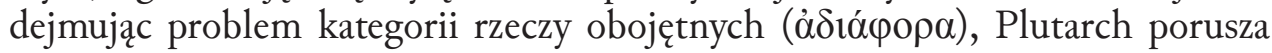
jedno z trudniejszych zagadnień etycznych, związanych bezpośrednio z decyzjami i działaniami podejmowanymi w codziennym życiu. Jeśli przyjąć, jak czynią

${ }^{3}$ Ujęcie to, wraz z kilkoma możliwymi wariantami interpretacyjnymi, znacznie szerzej omawia Tad Brennan (Brennan, 2005: 138-141). 
to stoicy, że jedynym dobrem jest cnota, a jedynym złem jej brak, to wszystkie pozostałe sprawy zostają przyporządkowane do kategorii tak zwanych rzeczy

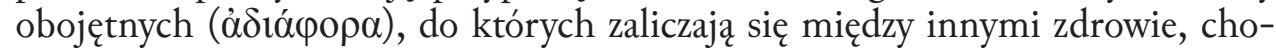
roba, bogactwo, ubóstwo czy też wysoka lub niska pozycja społeczna. Sprzeciw Plutarcha budzi fakt, że stoicy nazywają te rzeczy obojętnymi niezależnie od tego, czy są pożyteczne czy szkodliwe, a jednocześnie skupiają na nich swoje działania, starając się niektóre z nich zdobywać a innych unikać (Plutarch Comm. not. $1061 \mathrm{~b}-\mathrm{d})$. W efekcie mędrzec stoicki będzie popadał w sprzeczność, traktując rzeczy obojętne tak, jakby w istocie były czymś dobrym:

X

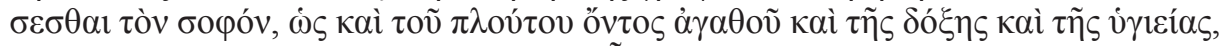

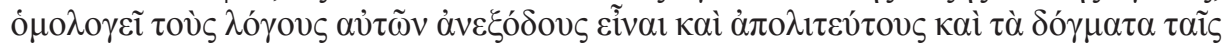

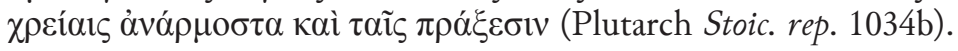

Znów Chryzyp, pisząc w swoim $O$ retoryce, że mędrzec winien w taki sposób przemawiać i uczestniczyć w życiu politycznym, jak gdyby dobrem było bogactwo, sława czy zdrowie, przyznaje, że ich wywody są nieżyciowe i niezgodne z duchem publicznym, same zaś nauki niedostosowane do praktyki i działania.

W tym miejscu wypada zauważyć, że problem kategorii ỏ $\delta$ á́ $\varphi \rho \rho \alpha$ oraz właściwego do nich stosunku budził niemałe kontrowersje również wśród samych filozofów Portyku, czego Plutarch nie uwzględnia w swoich traktatach. Szczególnie ciekawa wydaje się propozycja Arystona z Chios, aby z całkowitą konsekwencją traktować rzeczy obojętne tak, jakby nie były żadnymi, nawet relatywnymi, dobrami. Mędrzec odegra swoją rolę właściwie, niezależnie od tego, czy założy maskę Agamemnona czy Tersytesa (Diogenes Laertios VII 160). W takim wypadku pożądaną postawą byłoby niezabieganie o żadną z rzeczy potocznie uznawanych za dobre, jak również nieunikanie tych, które uchodzą za nieszczęścia. Jedynym zadaniem filozofa stoickiego miałoby być w tym rozumieniu bierne znoszenie zrządzeń losu, dzięki czemu realizowałby on postulat życia zgodnego z naturą-logosem. Ujęcie to zostało wprawdzie odrzucone przez główny nurt myśli stoickiej jako zbyt radykalne, pokazuje jednak, że problem ten był dostrzeżony i dyskutowany na gruncie stoicyzmu, a przedstawiciele tej szkoły nie zawsze dochodzili do tych samych wniosków i rozwiązań.

W pismach Cycerona zachowała się pewna interesująca metafora, którą Chryzyp posługiwał się, omawiając problem właściwego stosunku filozofa do rzeczy obojętnych:

Scite Chrysippus, ut multa, qui stadium, inquit, currit, eniti et contendere debet quam maxime possit, ut vincat, supplantare eum, quicum certet, aut manu depellere nullo modo debet; sic in vita sibi quemque petere, quod pertineat ad usum, non iniquum est, alteri deripere ius non est (Cicero De officiis III 42). 
Podobnie jak o wielu innych sprawach, także i o tym pięknie mówi Chryzyp: „Kto bierze udział w wyścigu biegaczy, winien jak tylko może najpilniej starać się i wytężać siły, by zapewnić sobie zwycięstwo; lecz żadną miarą nie godzi mu się podstawiać nogi lub odpychać ręką swego współzawodnika. Również i w życiu nie jest sprzeczne ze słusznością, kiedy każdy zabiega o to, co służy do zaspokojenia jego potrzeb; lecz nikt nie jest uprawniony do wydzierania czegoś drugim” (przeł. W. Kornatowski).

Metafora wyścigu okazuje się bardzo pomocna dla objaśnienia stoickiego stanowiska w kwestii rzeczy należących do kategorii ảóá $\varphi$ o $\alpha$. Filozofia stoicka, wyjąwszy przedstawioną wyżej propozycję Arystona z Chios, nie odmawia działającemu podmiotowi prawa do zdobywania tych rzeczy obojętnych, które są zgodne z naturą, a które potocznie uważa się za dobre. Pojęcie obojętności $\mathrm{w}$ tym przypadku oznacza jedynie tyle, że ani posiadanie którejkolwiek z tych rzeczy, ani też ich brak nie przyczynia się nawet w najmniejszym stopniu do życia szczęśliwego i cnotliwego, które polega na pełnej harmonii z naturą-logosem, co jest udziałem jedynie mędrca. Dla wszystkich ludzi niebędących mędrcami naturalne pole do działań stanowi właśnie sfera tego, co obojętne. Ryzykując trywializację stanowiska stoickiego, można by stwierdzić, że w normalnych warunkach lepiej być zdrowym i bogatym aniżeli chorym i biednym. Jedyne zastrzeżenie, jakie zostało tutaj uczynione jest takie, że w poszukiwaniu rzeczy obojętnych zgodnych z naturą (takich jak zdrowie czy bogactwo) nie wolno „podstawiać nogi lub odpychać ręką swego współzawodnika”, czyli dopuszczać się nieuczciwości i świadomie działać na czyjąś niekorzyść.

Z przytoczonego świadectwa Cycerona wynika jednoznacznie, że cytowane wyżej porównanie było (ut multa) stosowane przez Chryzypa często, nie miało charakteru jedynie wypowiedzi przypadkowej. Można zatem uznać za prawdopodobne, że argumentacja stoicka w tej kwestii była Plutarchowi znana lub że miał on przynajmniej możliwość się z nią zapoznać. Mimo to sformułowany przez niego zarzut zachowuje raczej charakter retoryczny niż filozoficzny, przede wszystkim ze względu na brak dostatecznej analizy czy chociaż pozbawionej uprzedzeń próby zrozumienia argumentów strony przeciwnej.

\section{ZARZUT DOTYCZĄCY MOŻLIWOŚCI ROZWOJU MORALNEGO (ПРОКОПН)}

Ostatnie problematyczne zagadnienie stanowi stoickie ujęcie rozwoju moralnego jednostki, które rzeczywiście może wydać się sprzeczne zarówno z codziennym doświadczeniem, jak i z podstawowymi intuicjami ze sfery moralnej. Stoicy utrzymują, że postęp moralny jednostki dokonuje się nie stopniowo, a w sposób nagły, na drodze całkowitej przemiany jakościowej człowieka głupiego, szalonego i zniewolonego w doskonale wolnego mędrca. W zasadzie brak tutaj jakichkolwiek stanów pośrednich, a każdy nie-mędrzec jest głupcem. Warto w tym 
miejscu zaznaczyć, że wniosek ten bywa podważany przez niektórych badaczy rzymskiego stoicyzmu, którzy wskazują na możliwość częściowego zbliżenia się $\mathrm{w}$ procesie rozwoju moralnego do stanu eudaimonii ${ }^{4}$.

Fakt, że takie ujęcie problemu kluczowego dla nieomal każdej teorii moralnej jest atakowane przez Plutarcha z pozycji zdroworozsądkowych, nie budzi większego zdziwienia. Podstawową wątpliwość stanowią przede wszystkim trudności związane z przełożeniem takiej teorii moralnej na codzienną życiową praktykę. Skoro każdy człowiek jest w takim samym stopniu głupcem, a jednocześnie mędrzec jest postacią niezwykle rzadko spotykaną, jak można komukolwiek powierzyć urzędy w państwie czy kogokolwiek obdarzyć zaufaniem w jakiejkolwiek sprawie? Przyjęcie stoickiej koncepcji rozwoju moralnego prowadziłoby więc wprost do sprzeczności na poziomie działania. Warto w tym miejscu zauważyć, że sami stoicy również zdawali sobie sprawę z problematyczności tego ujęcia, dlatego właśnie w literaturze starożytnej mówi się o paradoksach stoickich, czyli o takich właśnie twierdzeniach, które prowadzą do wniosków sprzecznych lub zaskakujących.

Szczególnie interesujące wydają się tu stosowane zarówno przez Plutarcha, jak i przez stoików, literackie porównania, które dość dobrze obrazują istotę sporu:

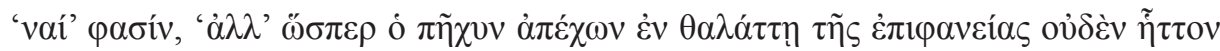

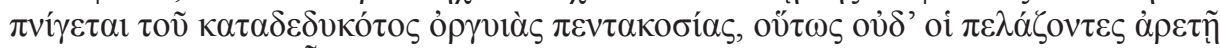

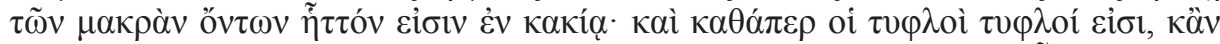

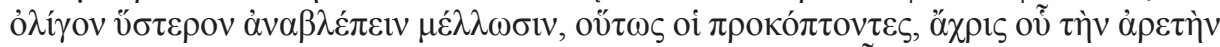

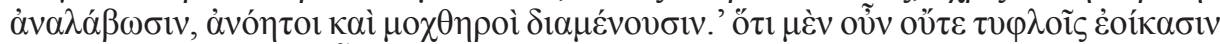

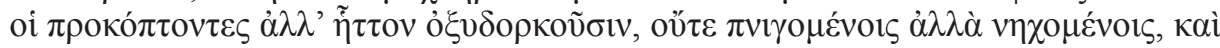

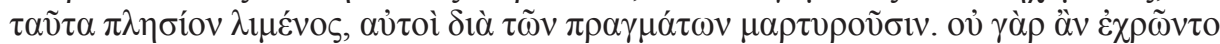

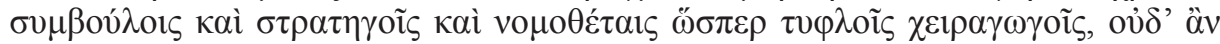

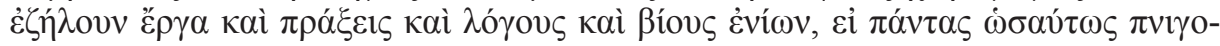

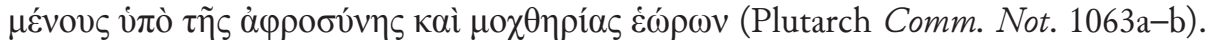

„Owszem”, mówią, „ale podobnie jak ten, kto jest na łokieć zanurzony w morzu, utonął nie mniej niż ten, kto na głębokość pięciuset mil, tak samo ci, którzy bliscy są cnoty, nie mniej niż ci, którzy są od niej jak najdalej, pogrążeni są w niegodziwości. A tak jak ślepi pozostają ślepymi, nawet jeśli niewiele później mają odzyskać wzrok, tak samo ci, którzy czynią postępy, pozostają nierozumni i niegodziwi, póki nie zdobędą cnoty”. Że jednak, ci, którzy dążą ku cnocie, nie są podobni do ślepców, ale do tych, którzy nie widzą jasno. I nie do tonących, ale raczej do tych, którzy płyną i są już blisko portu, o tym świadczyć mogą ich własne czyny. Nie używają bowiem doradców, strategów czy prawodawców $\mathrm{w}$ taki sam sposób jak ślepcy przewodników; nie naśladowaliby również dzieł, czynów, rozumowania czy żywotów, gdyby wiedzieli, że w podobny sposób tonęli w nierozsądku i podłości.

${ }^{4}$ Stephens, 2007: 122: „To the extent we succeed in modeling our art of living after the prescriptive ideal of the sage, to that extent we achieve eudaimonia as Epictetus understands it". 
Główna trudność polega na właściwej odpowiedzi na pytanie, czy między mędrcami a głupcami istnieje jeszcze grupa pośrednia, czyli ludzie, którzy osiągnęli szczęście i cnotę jedynie w pewnym stopniu i którzy mimo swoich niedoskonałości znajdują się na wysokim poziomie rozwoju moralnego. W ujęciu Plutarcha są to ci, którzy wprawdzie nie są już ślepi, lecz dopiero odzyskują wzrok, lub też ci, którym udało się dopłynąć blisko portu. Co zrozumiałe, ludziom takim bez obaw można zarówno powierzać stanowiska publiczne, jak i obdarzać ich zaufaniem, w przeciwieństwie do całkowicie zepsutych moralnie głupców.

Odpowiedź stoicka wskazuje przede wszystkim na to, że celem wszelkich dążeń moralnych jest osiągnięcie cnoty, która cechuje jedynie mędrca, a każda sytuacja inna od pożądanej będzie $\mathrm{w}$ równym stopniu nie tym, co pierwotnie zamierzało się uzyskać.

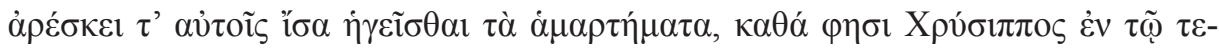

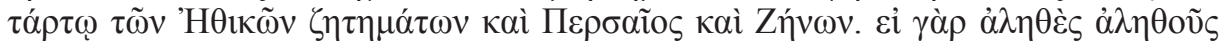

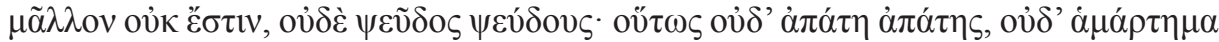

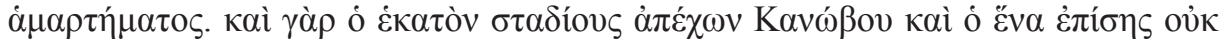

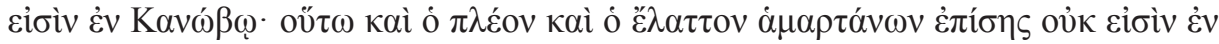

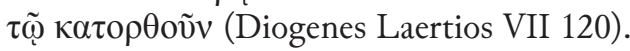

Wszystkie występki uważają za równe, jak mówi Chryzyp w czwartej księdze Zagadnień etycznych, a także Perseusz i Zenon. Skoro bowiem jedna prawda nie jest prawdziwsza od drugiej i jedno kłamstwo nie jest kłamliwsze od drugiego, tak samo i jedno oszustwo nie jest inne niż drugie i jeden występek inny niż drugi. Bo jak zarówno o tym, który jest o sto stadiów oddalony od Kanobos, jak i o tym, który jest tylko o jeden stadion od niego oddalony, trzeba powiedzieć, że nie są w Kanobos, tak samo i ten, kto więcej grzeszy, i ten, kto mniej grzeszy, są równie dalecy od dobrego postępowania (przeł. K. Leśniak).

Rzeczywiście, stanowisko stoickie w tej kwestii może wydać się trudne do zaakceptowania, nie jest jednakże tak, żeby ściśle dychotomiczny podział na mędrców i nie-mędrców wykluczał jakiekolwiek rozróżnienia w obrębie tej drugiej grupy. O ile prawdą jest, że każdy nie-mędrzec będzie w tym samym stopniu niezdolny do działania w pełni cnotliwego, czyli do formułowania sądów bezwzględnie prawdziwych (zwanych kataleptycznymi), a także do wykonywania czynów moralnie nienagannych (katorthomata), o tyle jednak dla nie-mędrców pozostaje otwarta sfera działań zgodnych z właściwymi im powinnościami ( $k a-$ thekonta), które określane są między innymi poprzez same nazwy funkcji społecznych (por. Epictetus Dissertationes II, 14. 8). A zatem dobry ojciec to ktoś, kto wykonuje obowiązki (kathekonta) właściwe ojcu, podobnie jak dobry syn czy dobry prawodawca. Możliwe jest więc, aby nie-mędrzec, podobnie jak inni pozbawiony możliwości działania $\mathrm{w}$ zgodzie $\mathrm{z}$ cnotą, mimo wszystko dobrze wykonywał obowiązki prawodawcy czy dowódcy wojskowego i był osobą godną 
zaufania. Poruszając podobny problem, Pierre Hadot wskazuje na dużą wartość dobrej intencji, która towarzyszy postępowaniu filozofa (będącego oczywiście nie-mędrcem) i która jakościowo odróżnia jego działania od tych podejmowanych przez człowieka takiej intencji pozbawionego (Hadot, 2004: 86).

Przy takiej interpretacji, znajdującej wystarczające uzasadnienie w tekstach źródłowych, różnica między ujęciem Plutarcha a stoickim zostaje zminimalizowana, przynajmniej na poziomie praktycznym. Tym samym można stwierdzić, że zastrzeżenia myśliciela z Cheronei, choć trafne ze zdroworozsądkowego punktu widzenia, dają się mimo wszystko odeprzeć na gruncie filozofii stoickiej.

\section{WNIOSKI}

Argumentacja, jaka pojawia się w analizowanych tekstach polemicznych Plutarcha, jakkolwiek w pełni zrozumiała ze zdroworozsądkowego punktu widzenia, nader często zdradza jego niedostateczną znajomość doktryny stoickiej, o czym najdobitniej świadczy zarzut dotyczący życia zgodnego z naturą. Za możliwe należy również uznać, że Plutarch nie wykazał wystarczająco dużo dobrej woli, by zrozumieć stanowisko stoickie w omówionych wyżej kwestiach, a jego polemika od początku naznaczona była intelektualnym uprzedzeniem. Warto przy tym dodać, że podobne tezy, wprawdzie jedynie na marginesie rozważań nad etyką stoicką, zostały sformułowane również przez innych badaczy w jednym z najlepiej znanych i cieszącym się największą renomą podręczniku do historii filozofii starożytnej, tj. The Cambridge bistory of Hellenistic philosophy ${ }^{5}$.

$\mathrm{Na}$ koniec jednakże należy zauważyć, że argumentacja Plutarcha, chociaż filozoficznie niezbyt trafna, zachowuje mimo to znaczną wartość w starożytnych sporach etycznych. Traktaty polemiczne przeciw stoikom są sprawnie napisane i zachowują dużą wartość jako tekst artystyczny, przez co w sposób efektowny zwracają uwagę na fakt, że stoickie tezy etyczne są nie tylko kontrempiryczne, ale co znacznie ważniejsze, zostały sformułowane w sposób niedostatecznie jasny, pozostawiający zbyt wiele miejsca na domysły, szczegółowe objaśnienia oraz interpretacje. Bez wątpienia stanowi to jeden $z$ najsłabszych punktów filozofii stoickiej, która w myśl swoich głównych przedstawicieli ma przecież stanowić nie tyle szkołę myślenia, co sposób życia.

\section{ZASADY PRZYWOŁYWANIA TEKSTÓW ŹRÓDŁOWYCH}

Numeryczne odwołania do tekstów Plutarcha odwołują się do standardowej paginacji stosowanej w naukowych edycjach Moraliów. Analogicznie, numeryczne odwołania w odniesieniach

\footnotetext{
${ }^{5}$ Inwood \& Donini, 2008: 725: „But we should beware of the risk of reading Stoic doctrine in the same way as its prejudiced and ill-disposed critics".
} 
do Platona - za ogólnie wykorzystywaną w wydaniach naukowych paginacją Stephanusa. Odniesienia do dzieł Diogenesa Laertiosa i Cycerona również za kanonicznym podziałem relewantnych tekstów przyjmowanym w edycjach krytycznych (księga, rozdział, paragraf).

\section{BIBLIOGRAFIA}

\section{Źródła:}

Arnim H. von (1964). Stoicorum Veterum Fragmenta. Stuttgart: Teubner Verlagsgesellschaft. Cicero. (1994). De officiis. (Wyd. M. Winterbottom). Oxford: Clarendon Press.

Cyceron. (1960). O powinnościach. W: Cyceron. Pisma filozoficzne (t. 2). (Tłum. W. Kornatowski). Warszawa: Państwowe Wydawnictwo Naukowe.

Diogenes Laertios (2004). Żywoty i poglady stynnych filozofów. (Tłum. I. Krońska, K. Leśniak, W. Olszewski, \& B. Kupis). Warszawa: Wydawnictwo Naukowe PWN.

Epiktet (1961). Diatryby. Encheiridion. (Ttum. L. Joachimowicz). Warszawa: Państwowe Wydawnictwo Naukowe.

Thesaurus Linguae Graecae ${ }^{\circledR}$ Digital Library. (Red. M. C. Pantelia). Irvine: University of California. Dostęp: http://www.tlg.uci.edu (28.12.2017).

Opracowania:

Brennan, T. (2005). Stoic life: Emotions, duties, and fate. Oxford: Clarendon Press.

Hadot P. (2004). Twierdza wewnętrzna. (Tłum. P. Domański). Kęty: Antyk - Marek Derewiecki.

Inwood, B. \& Donini, P. (2008). Stoic ethics (s. 675-738). W: K. Algra, J. Barnes, J. Mansfeld, \& M. Schofield (Red.). The Cambridge history of Hellenistic philosophy. Cambridge: Cambridge University Press.

Irvine, W. B. (2009). A guide to the good life: The ancient art of Stoic joy. Oxford: Oxford University Press.

Stephens, W. (2007). Stoic ethics: Epictetus and happiness as freedom. New York: Continuum International Publishing Group. 